\title{
0468. Cerebral effects of lateral trendelenburg vs semirecumbent position in an experimental model of ventilator-associated pneumonia
}

\author{
J López-Aguilar ${ }^{1,2^{*}}$, G Li Bassi ${ }^{2,3}$, ME Quílez ${ }^{1}$, JD Marti ${ }^{3}$, M Rigol $^{3}$, O Tavares-Ranzani ${ }^{3}$, E Aguilera $^{3}$, I Ferrer ${ }^{4,5}$, \\ L Blanch ${ }^{1,2,6}$, A Torres $^{2,3}$
}

From ESICM LIVES 2014

Barcelona, Spain. 27 September - 1 October 2014

\section{Introduction}

Lateral-Trendelenburg position has been postulated as a promising intervention to prevent ventilator-associated pneumonia (VAP) because it improves mucus clearance and avoids pulmonary aspiration in intubated patients [1]. Mechanical ventilation (MV) per se can modify brain status [2,3] but the effects of position during MV are unknown.

\section{Objectives}

To investigate the preventive effects of lateral Trendelenburg (TL) vs semirecumbent (SR) position in the development of VAP and its effects in the brain in an experimental model in pigs.

\section{Methods}

We have studied 17 Large White-Landrace pigs $(30 \pm 2 \mathrm{~kg})$ anesthetized, intubated and MV during $72 \mathrm{~h}$ in volume control. Animals were randomized in 3 groups:

1) SR: SR position, PEEP $0 \mathrm{cmH} 2 \mathrm{O}$, inspiratory-expiratory ratio (I:E) 0.33 ,

2) SR-inv: SR position, PEEP $5 \mathrm{cmH} 2 \mathrm{O}$, I:E 0.7, and

3) TL: TL position, PEEP 0cmH2O, and I:E 0.33.

All the animals were oropharyngeal instilled $(10 \mathrm{ml})$ with $P$ aeruginosa $\left(10^{7}-10^{8} \mathrm{cfu} / \mathrm{ml}\right)$. Mean arterial pressure (MAP) was monitorized and final bacterial pulmonary colonization, and cerebral status, consisting in a macroscopical evaluation of haemorrhage and of apoptosis indicatiors (caspase and TUNEL) in dentate gyrus in the hippocampal formation, were evaluated.

\section{Results}

Bacterial Colonization ( 0.22 vs 2.27 and $2.31 \log \mathrm{cfu} / \mathrm{gr}$, $\mathrm{p}<0.05)$ and VAP (0 vs 67 and $86 \%, \mathrm{p}<0.05)$ were drastically reduced in TL position as compared to SR and SR-inv respectively. MAP was lower in SR and SRinv compared to TL position (80 and 73 vs $90 \mathrm{mmHg}$, $\mathrm{p}<0.05)$. At the brain level, pigs in TL position presented high score of petequial hemorrhage (2.6 vs 1 and 1.5, $\mathrm{p}<0.05$ ), and higher levels of immunopositive cells to caspase (6.3 vs 2.5 and $1.7, \mathrm{p}<0.05)$ and TUNEL (5.17 vs 1 and $2.72, \mathrm{p}<0.05$ ) in the dentate gyrus in the hippocampus, both indicators of apoptosis, in comparison with groups SR and SR-inv respectively.

\section{Conclusions}

In this pig model of MV, TL position prevents pulmonary colonization and VAP development, but enhances cerebral hemorrhage, and increased apoptosis in the hippocampus. These alterations in the brain could be related with the increase in MAP observed in TL position. More studies to evaluate risks and benefits of TL position are needed.

\footnotetext{
Grant acknowledgment

Fundació Parc Taulí; MICIN PS09/01249; ESICM (2009 Alain Harf Award on Applied Respiratory Physiology); AGAUR GRC 532

\section{Authors' details}

${ }^{1}$ Fundació Parc Taulí, Sabadell, Spain. ${ }^{2}$ CIBERES, Madrid, Spain. ${ }^{3}$ Instituto del Torax, Hospital Clinic, IDIBAPS, UB, Barcelona, Spain. ${ }^{4}$ Idibell, Hospital Universitario de Bellvitge, L'Hospitalet de Llobregat, Spain. ${ }^{5}$ CIBERNED, L'Hospitalet de Llobregat, Spain. ${ }^{6}$ Corporació Sanitária i Universitária Parc Tauli-UAB, Sabadell, Spain.
} 


\section{References}

1. Li Bassi G, Torres A: Ventilator-associated pneumonia: role of positioning. Curr Opin Crit Care 2011, 17:57-63.

2. Quílez ME, López-Aguilar J, Blanch L: Organ crosstalk during acute lung injury, acute respiratory distress syndrome, and mechanical ventilation. Curr Opin Crit Care 2012, 18:23-8.

3. Quilez ME, Fuster G, Villar J, Flores C, Martí-Sistac O, Blanch L, LópezAguilar J: Injurious mechanical ventilation affects neuronal activation in ventilated rats. Crit Care 2011, 15:R124.

doi:10.1186/2197-425X-2-S1-014

Cite this article as: López-Aguilar et al:: 0468. Cerebral effects of lateral trendelenburg vs semirecumbent position in an experimental model of ventilator-associated pneumonia. Intensive Care Medicine Experimental 2014 2(Suppl 1):014.

\section{Submit your manuscript to a SpringerOpen ${ }^{\circ}$ journal and benefit from:}

- Convenient online submission

- Rigorous peer review

- Immediate publication on acceptance

- Open access: articles freely available online

- High visibility within the field

- Retaining the copyright to your article 